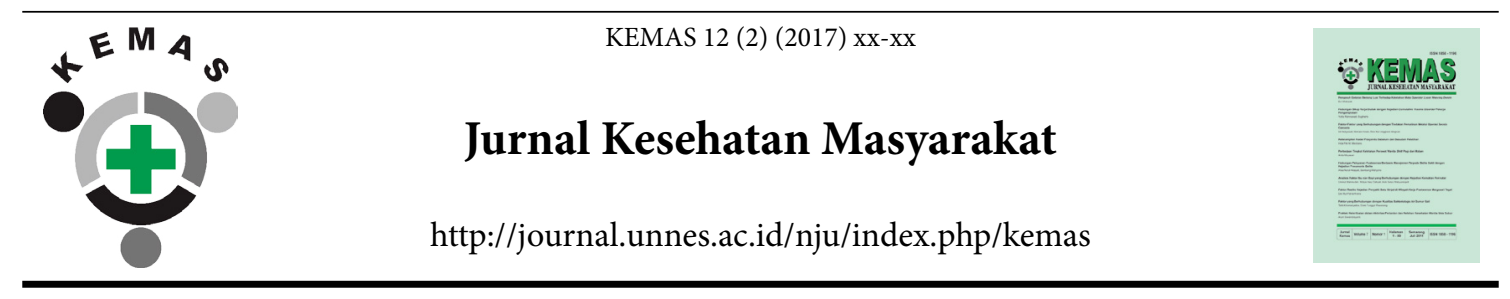

\title{
EARLY DETECTION OF HIGH RISK PREGNANCY
}

\author{
Arif Kurniawan $^{\bowtie}$, Colti Sistiarani, Bambang Hariyadi \\ Public Health Program, Faculty of Health,Universitas Jenderal Soedirman, Purwokerto
}

\section{Article Info \\ Article History: \\ Submitted 15 May 2016 \\ Accepted 20 January 2017 \\ Published January 2017 \\ Keywords: \\ high-risk; pregnancy; \\ early detection model \\ DOI \\ http://dx.doi.org/10.15294/ \\ kemas.v11i1.3521}

\begin{abstract}
There are 30.939 pregnant women in Banyumas, with 6.206 cases referred due to highrisk pregnancies. Petahunan village in Pekuncen has the the highest incidence of highrisk pregnancies compared with other villages. The purpose of this study is to describe the implementation of early detection of high-risk pregnancies in Petahunan village, Pekuncen. This study used qualitative research methods with case study approach. Research instruments used in-depth interviews and focus group disscussion toward early detection of high-risk pregnancy issue. The informants were 7 people include pregnant women, health workers, midwives, head of village and village health forum chairman. The result showed only antenatal care implemented to detect high-risk pregnancy and no programs and community empowerment efforts in early detection of high-risk pregnancies.
\end{abstract}

\section{Introduction}

Maternal mortality cases in Banyumas are distributed evenly in every Puskesmas (primary health care). Maternal deaths in Banyumas ranks 6 out of 35 districts in Central Java in 2012 with 34 mortality. The incidence of maternal deaths in 2013 were 3 cases in Puskesmas Pekuncen and Puskesmas Banyumas, 2 cases in each Puskesmas Purwokerto Barat, Sumpiuh II, Kemranjen II, Purwokerto Timur, Kembaran II, dan Baturaden II, the rest 1 case in each Pukesmas Lumbir, Tambak I, Cilonggok I, Baturaden I, Kedung Banteng, Somagede, Ajibarang I, Jatilawang, Karang Lewas, dan Baturaden II. Eclampsia and hemorrhage were the largest contributing cause of maternal death in Banyumas that is $8.13 \%$ and $7.27 \%$, respectively. Eclampsia and hemorrhage occurr in the group of high-risk pregnant women that can be addressed by excellence antenatal (prenatal) care and community empowerment for the early detection of high-risk pregnancies. Lack of public awareness about the maternity health become a determinant in maternal mortality.

The three main causes of maternal death are heart disease, preeclampsia / eclampsia, and hemorrhage. These three research variables, such as pregnancy complications, labor complications, and history of the disease, may affect to maternal mortality. It is suggested for mother to do early detection of risk factors and potential obstetric complications, especially in labor, in order to make prevention effort optimally (Aeni, 2010). Some factors such as maternal age, history of disease, educational level, had a significant relationship with the occurrence of severe pre-eclampsia. It is recommended that counseling for pregnant women is needed to detect the early signs

\footnotetext{
$\square$ Correspondece Address:

Gedung B Jl.Dr. Suparno, Karangwangkal Purwokerto

Email : arif_kurnia78@yahoo.com
} 
and symptoms of pre-eclampsia (Yulianti and Fikawati, 2008). Previous studies were more emphasis on factors that related to the incidence of high-risk pregnant women, and suggest the early detection of high-risk pregnancies, but had not examined on how to develop the model of early detection of high-risk pregnancies in rural area.

The number of pregnant women in Banyumas in 2012 is 30,939, with 6,986 pregnant women have risk factors detected on health provider and 4,072 pregnant women detected on community. The referral of highrisk maternal cases in Banyumas is 6,206 of pregnant women. It shows that the number of pregnant women is high as much as $20.05 \%$ of all pregnant women. Hence, early detection program of high-risk pregnancies might not be implemented optimally. This study aim to describe the implementation of early detection of high-risk pregnancies in the rural area. This study is conducted as a case study in Petahunan village, Puskesmas Pekuncen, which have higher risk of pregnancies compared to the other villages.

\section{Method}

This study used a qualitative research method. The sample of the study was the pregnant women, midwives, health workers, chairman of local health forum, and the head of village. We used purposive sampling method and recruited the key informants and comparison informants as much as 7 people: 2 pregnant women, 2 health workers, 1 midwives, 1 chairman of local health forum, and 1 head of village. The data collected through depthinterview and focus group discussion. The inclusion criteria of pregnant women who were detected had high-risk pregnancy. The exclusion criteria of the pregnant women who were permanently settled in Petahunan village. This study was conducted in 2015 in Petahunan village, Puskesmas Pekuncen. Petahunan village was the area with large cases of high-risk pregnancies.

This study recruited the comparative informants as a part of triangulation of source which was by conducting focus group discussion between health workers, midwives, chairman of local health forum, and the head of village. This study used a triangulation technique to maintain the validity of data sources. The qualitative data analyzed with interactive analysis model.

The research ethic was applied through request a permission to the local village administrative by explain the aim and purpose of the study, honor and respect the rules, norms, traditions, and beliefs in the local area as well as maintain confidentiality of information given by the informants. We explained all information about the study to the informants previously, then asked them for consent to become informants in this study.

Qualitative data analysis performed in this study was using a flow of activities as follow: data collection, data reduction, data presentation, and finally draw a conclusion. Data analysis was performed interactively and continuously over time until the data was saturated. The qualitative data presented was already passed the reduction and verification of data, from the transcription of in-depth interviews to be research information/data.

\section{Results and Discussion}

The results of the study indicated that a high risk pregnancy cases in the Petahunan village according to informant 1 (midwives) occurred due to pregnancy age was too young under 20 years and Chronic Energy Deficiency (CED).

\footnotetext{
"For Petahunan village, mostly the high-risk pregnancy was actually due to age, so in the cases a high-risk there were many classifications. But, in Petahunan, more likely the cause was the age and CED (Chronic Energy Deficiency) cases. Even, Chronic Energy Deficiency case was only in 2 or 3 women. Mostly due to the age under 20 years old." (Midwife)
}

High cases of too young pregnant women was because of early marriage, while for the case of CED there were currently only two pregnant women. Respondent 3 (Posyandu (Community Health Center) worker) and the respondent 4 (head of village) also stated that the case of high-risk pregnancies in the village was due to the pregnant women in a young age.

Unwanted pregnancies occurred in adolescents aged under 19 years old is caused 
by sexual behavior before marriage. Result of Azinar research (2013), showed that sexual behavior of close friend, the respondents' attitudes toward sexuality, and religiosity dominantly influenced premarital sexual behavior led to unwanted pregnancies in adolescents.

At-risk pregnancy is a state of circumstances that may affect the optimization of both mother and fetus in pregnancy. Age less than 19 years old or over 35 years is a risk factor for high-risk pregnancies (Manuaba, 2012). Factors causing high-risk pregnant mothers in the years 2005-2010 in Polindes Sambikerep Nganjuk showed $29.6 \%$ of pregnant women experiencing high-risk pregnancies affected by several interrelated factors, particularly non-medical factors that could affect medical factors, causing delays in the handling of highrisk pregnancy (Ambarwati, et al., 2011).

Informant 1 (midwife) stated that the program of early detection of high-risk pregnancies in the Petahunan village was limited on examination during pregnancy only. The statement was also supported by the second respondent (pregnant women) who stated no related programs on pregnant women, particularly the early detection of highrisk pregnancies. Methods of early detection of high risk pregnancies conducted by Informant 1 (midwife) was performing anamnesis and physical examination. Anamnesis conducted by midwives was about the age and medical history of pregnant women. Physical examinations performed over pregnant women were upper arm circumference measurement determining the nutritional status, weight, height of the pregnant women, and blood pressure measurement. Additionally, midwives collaborated with health workers/cadres, the family of pregnant women, and other people in community to share information about the pregnancy problems of the pregnant women, in addition to early detection performed by midwives.

Maternal nutrition status may influence the level of maternal and infant morbidity, where it may contribute in the high allocation of health financing. Underweight or overweight women have an increased risk of hypertension in pregnancy, gestational diabetes, as well as the possibility of giving birth by cesarean surgery. (Denison, 2013)

It indicated that the health worker was still passive waiting for pregnant women to check up. The results showed that the Local health forum had not been able to conduct introspective surveys, especially in the field of detection of high-risk pregnancies. However, local health forum ever conducted a counseling for pregnant women with the midwife as key speaker.

The role of village government related to high risk pregnancies was conducted in Alert Village program. On Alert Village program carried out recruitment of women at high-risk pregnancies, which being follow-up then by Public Health Office and then returned back to the village midwives and village officials. Midwives with the village officials solved the problems, as well as motivated the at-high-risk pregnant women to perform regular checkups and proper preparation for labor.

\begin{abstract}
"Through Alert Village program we could detect the high-risk pregnancies. Some of them were managed by Public health office then returned back to the village. And some of the women were aware of their health and pregnancy condition, and some of them were too lazy. So, what we could do was giving motivation in order to make them more diligently to care, more frequent to control. While, the $\mathrm{Hb}$ (Hemoglobin) monitoring can be done in Puskesmas, but not all of the pregnant women wanted to check the Hb level." (Midwife)
\end{abstract}

Handling model of high-risk pregnant mothers was discussed in the Focus Group Discussion held on Saturday, August $30^{\text {th }}, 2014$ at the Hall of Petahunan village, District of Pekuncen. Participants of this activity were the village midwives, head of village, chairman of local health forum, village government officials, and cadres of Posyandu (Community health center).

Efforts made by midwives and cadres on the early detection of high-risk pregnancy was through examination of pregnancy only in pregnant women who checkups. 
"Program of early detection on highrisk pregnancies in the Petahunan village was not available yet, even only during pregnancy period of the women. Anamnesis that usually done was about the age and medical history of pregnant women. I also performed a physical examination of pregnant women by measuring the upper arm circumference to determine the nutritional status, weight, height of the pregnant women and measured the blood pressure, and I also worked with health cadres, the family of pregnant women and other people in community to share information about the pregnancy." (midwife).

"Usually, at the time of reporting, I teamed up with a midwife in other regions via mobile phone by SMS or telephone, because there were some pregnant women in the region of Petahunan but they came for check up to the midwife in another village, Gumelar village in example, due to the nearer access. Petahunan village was divided into 2 regions, the region 2 was located far away and there are still traditional birth attendants in the that area. But, I always attend to region 2 , so at some time in region 1 , and some time switching to region 2 to provide the access." (midwife)

It was also reported by the health worker and chairman local health forum that the detection of high-risk pregnancies was still the sole responsibility of midwives and village health forum has not made particular coordination efforts to discuss these issues in the meeting of villagers.

"In petahunan, there is no special meeting related to high-risk pregnant women issues, also there is no socializations for teenagers, for example from the puskesmas to the school and outside the school is also yet conducted" (Chairman FKD).

However, the results showed early detection efforts were still rely on awareness of pregnant women to take antenatal care at midwives. The results showed the absence of involvement of Village Health Forum, cadres, and pregnant women in the early detection of high-risk pregnancies. The results showed that the village midwife, head of the village, Forum Village Health and Maternal Health Cadre have a demand to implement early detection of highrisk pregnancies.

The results showed that efforts to detect high-risk pregnancies in the village health center Petahunan Pekuncen limited to examination during pregnancy only. There were no specific programs related to early detection of the risk of pregnancy. Methods of early detection of highrisk pregnancies conducted by midwives was by anamnesis and physical examination. Posyandu cadres informant stated early detection of high-risk pregnancies performed by midwives, Posyandu cadres only help midwives to provide the required information for midwife especially with regard to pregnant women.

The results indicated the performance of midwives in the detection of high-risk pregnancy due to the limited number of midwives and geographical conditions of work location. Results Ristrini study (2014), showed that midwives had a leading role in efforts to improve the early detection of high-risk pregnancies through completion of Maternal and Child Health (MCH) record book by midwives in Bangkalan, East Java. Completeness of KIA book in pregnant women associated with motivation and workload of the midwives. There was no relationship between the midwife incentive to detect highrisk pregnant women with maternal mortality in Kampar (Lestari, 2012). This suggested that early detection of high-risk pregnancies may not depend only on the village midwife.

Health Cadres have important roles in empower mother's activeness in improving maternal and child health. One of them was cadre role in the use of $\mathrm{MCH}$ record book. $\mathrm{MCH}$ record book can be used to monitor the risk factors of pregnancy in women. Sistiarani research results (2013) showed that knowledge was related to the role of cadres in the use of $\mathrm{MCH}$ record book, while the motivation and working period were not related to the role of cadres in the use $\mathrm{MCH}$ record book.

The empowerment efforts of pregnant women for early detection of high-risk pregnancy during first trimester at a Posyandu 
in Puskesmas Jagir, Surabaya, showed that empowerment efforts of pregnant women had no effect on capability of mothers in early detecting the risk-factors (Sugiarti, 2012). The results showed the roles of health cadres in Petahunan village in early detection of high-risk pregnancies were still limited, only at Posyandu. Health cadres had not been making efforts yet for early detection of high-risk pregnancy due to lack of knowledge and skills for early detection of high-risk pregnancies. The level of knowledge on danger signs in pregnancies in Bolon village, Colomadu District showed that the level of knowledge among health cadres on pregnancy danger signs in Bolon village was moderate as much as 20 respondents $(66.7 \%)$ (Palupi, 2013). The roles of health cadres that had been implemented were antenatal care which has reached $100 \%$, the installation of First Aid stickers had reached $94.0 \%$, the storage of $\mathrm{MCH}$ record book by pregnant women has reached $88.1 \%$, counseling of new traditional birth attendants had reached $73.1 \%$, Local Regional Monitoring together with new midwives had reached 59.7\%, cadre who had not given $\mathrm{MCH}$ record book to pregnant women had reached $25.4 \%$, and referred to health centers had reached 62.7\% (Mikrajab and Rachmawaty, 2012). While the research results of Lestari (2013), showed that there was no correlation between the characteristics and roles of health cadres in the early detection of the high-risk pregnancy in Puskesmas Nanggalo, Padang.

The results showed that early detection efforts were still rely on awareness of pregnant women in conducting the antenatal care at midwives. The results showed that the absence of involvement of Village Health Forum, health cadres, and pregnant women in the early detection of high-risk pregnancies. Empowerment of pregnant women for early detection of high-risk pregnancy during first trimester in Puskemas Jagir, Surabaya. This study was a pre-experiment, with one-group pretest-posttest design. Results showed that there was no effect of efforts to empower pregnant women's competency to detect their early risk factors. But, personal autonomy showed $p=0.047(p<0.05)$ which showed a significant effect on the ability to detect early high-risk pregnancies. Pregnant women with better personal autonomy would detect their pregnancy and able to choose the health care institution (Sugiarti, 2012).

Early detection of high-risk pregnancy can be done by health workers or trained non-medical workers in the community. Early detection of high-risk pregnancies can separate group of pregnant women without risk from group with risk factors. The case of high-risk pregnancies in Petahunan village, Puskesmas Cilongok was in the category of young primigravida, the first pregnancy at age $<16$ years, which was the uterus and pelvis had not develop to adult size yet. Consequently, safety and health of the fetus in the womb were uncertain. Maternal mentality was not mature enough. Risks that may occur include: premature baby, hemorrhage could occur before the baby is born, hemorrhage may occur after the baby is born.

The higher prevalence of high-risk pregnancies experienced in group of mothers who have low education level (36.7\%) and lower social status (33.4\%) than in the group of mothers who have high education level (24.9\%) and higher social status (19.7\%). Early identification and treatment of highrisk pregnancy may prevent maternal and fetal development defect. Women education with motivation and health professionals' efforts were important for maternal safety (Bharti, 2013).

Special health cadre for women is one of things can be done to bring access of reproductive health services to rural area. This is importance to equipping health cadres for pregnant women through skills and equipping them with necessary equipments for early detection of pregnancy, so they enable to make referrals to appropriate healthcare. The roles of health cadres for women are focused on the early detection of pregnancy by urine testing, counseling, referral to appropriate antenatal care, safe abortion and family planning programs (Kathryn, et al., 2013).

These results indicated that the highrisk factors of pregnancy in the study site were young primigravida. Young primigravida is young pregnant woman under 20 years old. The main cause of pregnancy at young 
age was caused by high-risk sexual behavior before marriage or marriage at early age. The results of Focus Group Discussion on this study indicated that the effective models for preventing high-risk pregnancies at young age mothers under 20 years old were promotion and education of adolescent reproductive health. Efforts of antenatal examination by midwives through antenatal services by cooperation or coordination with other midwives in rural region may provide early detection of highrisk pregnancies. Empowerment of rural health forums, health cadres, and pregnant women in coordination with the midwives in early detection can help midwives to early detection of pregnancy. However, it is necessary to increasing the capacity of rural health forums, health cadres and pregnant women in the early detection of high-risk pregnancies.

This study showed that the midwives, head of the village, Forum Health Village and Maternal Health Cadres have demand to implement early detection of high-risk pregnancies. Empowerment of pregnant women for early detection of high-risk pregnancy during first trimester in Puskesmas Jagir, Surabaya. This study was a preexperiment, with one-group pretest-posttest design. Results showed no effect of efforts to empower the pregnant women's ability to detect their early risk factors. But personal autonomy showed $p=0.047(p<0.05)$ which showed the significant effect on the ability to detect early high-risk pregnancies. Pregnant women with better personal autonomy would detect their pregnancy and can choose health care institution (Sugiarti, 2012).

Implementation of delivery planning program and prevention of complications by early detection of high risk pregnant women showed correlation between implementation of delivery planning program and prevention of complications by early detection of mothers with high risk pregnancies has $p$ value $=0.0001$. This showed that pregnant women who did not understand delivery planning program and prevention of complications did not stick the stickers and tend to have less ability in early detection of high-risk pregnancies. The success of delivery planning program and prevention of complications was determined by pregnant women and health cadres. Pregnant women get information about delivery planning program and prevention of complications from midwives, but the information obtained was incomplete. Midwives only gave explanation about the contents of delivery planning program and prevention of complications stickers and did not mention the purpose and benefits of delivery planning program and prevention of complications stickers (Mulyati, 2012).

The delivery planning program and prevention of complications with early detection in the Puskesmas Petahunan, Pekuncen, Banyumas was still incomplete. Petahunan village midwife did not facilitate this program optimally even if the midwife had been provided antenatal care and information about high-risk pregnancy. Pregnant women in the village Petahunan still had little knowledge about high-risk pregnancies, early detection's ability was low on high-risk pregnancy, health workers still had limited role in early detection. Role of Rural Health Forum was not optimal to deliberate the villagers to discuss the high-risk pregnancy and how to handle it.

Effective methods of health promotion to increase early detection of the risk of pregnancy in pregnant women, health workers and Village Health Forum still had not been examined. Knowledge and attitudes regarding high-risk pregnant women before and after counseling in the working area of Puskesmas Muara Fajar, Pekan Baru just showed the differences in knowledge about high-risk pregnancy before and after counseling. There was an increasing attitude of high-risk pregnancies before and after counseling (Restuastuti, 2009).

In a risk-approach strategy, screening activity is an important component in pregnancy care, to be followed by Information, Education and Communication (IEC) to pregnant women, husband, and family, to do a planning of safe delivery with a planned referral when needed. Through this activity, there are several risk factors in pregnant women that has a prediction / estimation value of a wide possibility of complications that will occur. Therefore, screening activity must be done repeatedly so it can caught early risk factors which will develop further in gestation.

Widiastuti's study (2014), showed that 
the management of early detection of high risk pregnant women affected by the planning, guidance and supervision / monitoring. Puskesmas has a low coverage ratio of midwives per population, standard operation procedure has not been affixed, the planning is carried out per year, the coaching is done every six months and the supervision feedback results is delivered orally. Puskesmas with high coverage also have low midwives per population ratio, the planning is carried out per month through mini workshops, coaching is done per month, supervision feedback results is submitted in writing with sanctions if reports late.

Midwifery care is needed in order to do a basic obstetric care, for examples increased awareness of midwives to pregnant women of high-risk such as mutuality, trust, ongoing dialogue, as well as mentoring. Responsibilities of midwives to undertake health promotion through providing information about pregnancy care including antenatal care (Berg, 2005).

Pregnant women who are diagnosed late have high probability of complications. Human resources and quality of maternal emergency services in developing countries is insufficient. Shortage of staff is the main obstacle to providing quality service. The concern for pregnant women with high-risk pregnancy can have consultation, and their families can play a supporting role to get help from a health professional (Dogba, 2009).

\section{Conclusion}

Early detection of high-risk pregnancies at the village level Pekuncen is limited to examinations during pregnancy in the village midwife. There are no special programs related to early detection of the risk of pregnancy. Methods of early detection of high-risk pregnancies conducted by midwives are anamnesis and physical examination. The results showed there was no community empowerment efforts in the early detection of high-risk pregnancies in neither activities nor non-governmental funding.

\section{Referrences}

Aeni, N. 2010. Faktor Risiko Kematian Ibu. Jurnal Kesehatan Masyarakat Nasional. 7 (10) : 453459.

Ambarwati MR, Yuliana R, dan Wisnu NT,. 2011.
Gambaran Faktor Penyebab Ibu Hamil Resiko Tinggi Tahun 2005-2010 (Di Polindes Sambikerep Kecamatan Rejoso Kabupaten Nganjuk). Jurnal Penelitian Suara Forikes. 2 : $1-8$.

Azinar, M. 2013. Perilaku Seksual Pranikah Berisiko Terhadap Kehamilan Tidak Diinginkan, Jurnal KEMAS Unnes, 8 (2).

Berg, M. 2005. A Midwifery Model of Care for Childbearing Women at High Risk: Genuine Caring in Caring for the Genuine. Journal Perinatal Education. 14 (1) : 9-21.

Bharti, et al. 2013. Prevalence and Correlates of High Risk Pregnancy in Rural Haryana: A Community Based Study. International Journal of Basic and Applied Medical Sciences.

Dogba M, Fournier P. 2009. Human Resources and The Quality of Emergency Obstetric Care in Developing Countries : Systematic Review of Literatur. Hum Resources Health, 7 (7).

Denison, et al. 2013. Asociation Betwen Maternal Body Mass Index During Pregnancy Short Term Morbidity and Increased Health Services Cost A Population Based Study. Journal Obstetric and Gynaecology. 121 (1) : 72-82.

Kathryn, A. et al. 2013. Early Pregnancy Detection By Female Community Health Volunteer in Nepal Facilitated referral to Appropriate Reproductive Health services. Global Health Science and Practices. 1 (3): 372-381.

Lestari N. 2012. Hubungan Pemberian Insentif Deteksi Bumil Risti dengan Upaya Penurunan Kematian Ibu di Kabupaten Kampar 2012. Jurnal Kesehatan Reproduksi. 3 (3) : 124-131.

Lestari W dan Halida E.M, 2013. Hubungan Karakteristik Dengan Peran Kader Dalam Deteksi Risiko Kehamilan Di Wilayah Kerja Puskesmas Nanggalo Padang, e- journal. Mercubaktijaya.ac.id. 6 (2).

Manuaba, 2012. Ilmu Kebidanan, Penyakit Kandungan dan Keluarga berencana Untuk Pendidikan Bidan. EGC. Jakarta

Mulyati dan Yuliastanti T. 2012. Implementasi Program Perencanaan Persalinan dan Pencegahan Komplikasi dengan Deteksi Dini Ibu Hamil Risiko Tinggi. Jurnal Kebidanan. 4 (2).

Palupi, FH, Fakhidah LN, dan Utami U,. 2013. Tingkat Pengetahuan Kader Kesehatan tentang Tanda Bahaya Kehamilan di Desa Bolon Kecamatan Colomadu. Jurnal KESMADASKA. 4 (1) : 43-46.

Restuastuti, Handayani, dan Yanti Ernalia, 2009. Pengetahuan dan Sikap Ibu Hamil Tentang Kehamilan Risiko Tinggi Sebelum dan 
Sesudah Penyuluhan di Wilayah Kerja Puskesmas Muara Fajar Kota Pakan Baru, Laporan Penelitian, Universitas Riau

Ristrini dan Oktarina, 2014, Upaya Peningkatan Deteksi Dini Risiko Tinggi Kehamilan Melalui Kelengkapan Pengisian Buku KIA Oleh Bidan di Kabupaten Bangkalan Jawa Timur Tahun 2013, Buletin Penelitian Sistem Kesehatan. 17 (3) Juli 2014 : 215-225

Sistiarani C, Nurhayati S dan Suratman, 2013, Faktor Yang Mempengaruhi Peran Kader Dalam Penggunaan Buku Kesehatan Ibu dan Anak. Jurnal Kemas Unnes, 8 (2)

Sugiarti, S.O, dan Mochny IS,. 2012. Upaya
Pemberdayaan Ibu Hamil Untuk Deteksi Dini Risiko Tinggi Kehamilan Tri Mester Satu. The Indonesian Journal of Public Health. 9 (1) : 27-36.

Widiastuti T, Kartasurya M.I, dan Dharminto, 2014, Manajemen Deteksi Dini Ibu Hamil Risiko Tinggi Pada Pelayanan Antenatal di Puskesmas Kabupaten Jepara, Jurnal Manajemen Kesehatan Indonesia, 2 (3).

Yulianti, L, dan Fikawati S. 2008. Pre-Eklampsia Berat di RSUD Bayu Asih Purwakarta. Jurnal Kesehatan Masyarakat Nasional. 3 (1) : 154160. 